\title{
AS TUTELAS DE URGÊNCIA COMO ALTERNATIVA À SUPERAÇÃO DO PROCEDIMENTO ORDINÁRIO ${ }^{1}$
}

\author{
Priscila Cardoso Werner ${ }^{2}$ \\ Angela Araújo da Silveira Espindola ${ }^{3}$
}

\begin{abstract}
RESUMO: A morosidade na prestação da tutela jurisdicional revela as consequiências da insuficiência do sistema processual brasileiro. Não há dúvida de que o aparelho judiciário com raízes no racionalismo dos séculos XVIII não está apto a suportar os avanços e promessas da modernidade. O presente estudo elucida a presença do racionalismo nas tutelas de urgência e aponta para o conceito das cautelares no direito processual brasileiro. Para tanto, partiu-se do direito romano analisando os interditos e o "acontecer" da predominância da plenarização e dos juízos de certeza. Desse modo, constatouse a importância das tutelas cautelares para a sociedade contemporânea imersa em conflitos cada vez mais complexos. Por conseguinte, advém, a necessidade de reconhecer na tutela cautelar um direito substancial e não vincular somente sua proteção à garantia de um processo principal.
\end{abstract}

PALAVRAS-CHAVE: Tutela de urgência, racionalismo.

\section{The Urgency Protections as Alternative to the Overcoming of the Ordinary Procedur}

\begin{abstract}
The slowness in the installment of the jurisdictional protection reveals the consequences of the inadequacy of the Brazilian procedural system. There is no doubt that the judiciary apparel with roots in the rationalism of the centuries XVIII is not capable to support the progresses and promises of the modernity. The present study elucidates the presence of the rationalism in the urgency protections and it appears for the concept of the precautionary ones in the Brazilian Procedural Law. For so much, it starts with the Roman law analyzing the injunctions and happening of the predominance of the plenary and certainty. This way, the importance of the precautionary protections was verified for the contemporary society immersed in conflicts more and more complex. Of that it occurs, the need to recognize in the precautionary protection a substantial law and not to link only his protection to the warranty of a main process.
\end{abstract}

KEY-WORDS: Urgency Protections, rationalism.

\footnotetext{
${ }^{1}$ Resultado da pesquisa realizada para o trabalho de conclusão de curso intitulado "O princípio da fungibilidade entre as tutelas de urgência: uma herança do paradigma racionalista", concluída em 2005/1, junto ao curso de graduação em Direito no Centro Universitário Franciscano (UNIFRA).

${ }^{2}$ Especializanda do Curso de Pós-Graduação em Direito Civil da UFSM. Advogada. E-mail: priscila.werner@gmail.com. ${ }^{3}$ Orientadora. Doutoranda e Mestre em Direito pela Universidade do Vale do Rio dos Sinos (UNISINOS). Advogada e Professora da Faculdade de Direito de Santa Maria - FADISMA. E-mail: angela@fadisma.com.br.
} 


\section{Introdução: as Tutelas de Urgência no Direito Romano - a supressão dos interditos}

A reflexão sobre o excessivo tempo de duração das demandas constitui temática recorrente, estando constantemente em pauta dentre os juristas. De longa data, ou mais precisamente, desde o Direito Romano é percebida uma preocupação com a efetividade do processo devido à morosidade das demandas, conforme adverte Carmignani (2000, p.09). Para resolver tal problemática, inseriu-se dentre as tutelas pretorianas, os interditos, consistindo num procedimento mais ágil oferecendo proteção ao titular do direito aparentemente lesado através de cognição sumária.

Os interditos visavam, segundo Carmignani (2001, p.17), dirimir os obstáculos da aplicação tempestiva dos direitos. Desse modo, para a doutrinadora era possível quebrar com a morosidade e formalidade do procedimento da actio, concedendo a tutela interdital oportunamente (2001, p.18). Esse período era denominado de clássico tendo enorme relevância, pois se obteve uma abertura das fórmulas, estendendo-se o direito ao conflito social. Assim, Cruz e Tucci (2001, p.114) adverte a faculdade do pretor adaptar a fórmula de um interdito para uma situação análoga e, ainda, conceder o interdito para uma nova situação.

No poder de império do pretor romano, salienta-se de acordo com Ferreira (1983, p.44), os primeiros resquícios de uma medida cautelar, quando através dos interditos podiam-se assegurar os bens de uma parte ofendida para uma futura execução. Nesse sentido, o autor exemplifica como poder geral de cautela a missio in possessionem, sendo "uma medida preventiva e por isto mesmo cautelar pela qual o pretor ordena entregar a coisa que é objeto de um litígio a um litigante ou a um curador" (1983, p.45).

Assim, os interditos para Birchal (2002, p.216) foram as primeiras manifestações do processo cautelar. Ademais, os interditos possuíam a cognição sumária, tendo em vista, a análise dos fatos e a concessão ou não da ordem segundo o referido doutrinador. Tal cognição era realizada oralmente diante do pretor, e caso fosse acatada tal ordem o litígio ficaria encerrado, diante desse poder de império do pretor. Caso contrário, passar-se-ia ao estabelecimento da litis contestati e redação da fórmula, nomeando-se o Jurisconsulto para decidir o litígio definitivamente, tendo como base a fórmula redigida pelo pretor.

Entretanto, o caráter impositivo do pretor romano não prevaleceu sendo predominado pelo procedimento da actio, ou seja, a mera declaração do direito descumbida do poder de império. Com isso, há uma supressão das fases do período fórmular, inaugurando-se o período 
extraordinário onde o próprio magistrado instruía e julgava o feito. Ao longo dos anos, percebe-se a presença da actio em detrimento do interdicto, ambos, institutos do direito romano de proteção e defesa dos indivíduos. Desse modo, começa-se o detrimento dessas tutelas diferenciadas em favor da plenitude da defesa e segurança jurídica, sendo imprescindível para alcançar tais objetivos uma cognição exauriente.

Assim, foi sendo concebido o direito, primeiramente abstraindo-se o fato da norma com a resolução dos casos pelos jurisconsultos que passaram a aplicar a norma abstratamente como numa dedução matemática. Dito de outro modo, o jurisconsulto decidia conforme a fórmula redigida pelo pretor e, em consequiência, não 'sentia' o contato com as circunstâncias fáticas 'escondidas' através da redação da fórmula do pretor.

Posteriormente com a universalização deste procedimento substituindo-se a força executiva dos interditos pelo procedimento da actio, e por conseqüência desvalorizando-se a cognição sumária e a oralidade exercida diante do pretor romano, foi fácil obter uma norma distante da realidade social. A partir de então, até os dias atuais convive-se com a norma distante da realidade social! Por derradeiro, esta generalização da norma, conduziu o processo outrora, para servir como instrumento de poder e autoritarismo dos Reis que temiam a interpretação e autonomia dos magistrados.

Por conseguinte, com a supressão dos interditos do Direito Romano perde-se em efetividade e evidencia-se posteriormente uma tendência de codificação dos direitos. Como bem adverte Wolkmer, aproxima-se o direito à lei e esvazia-se com a idéia de justiça (2000, p.26). Na verdade, pretendeu-se 'geometrizar' conflitos sociais como se isso fosse possível, com intuito de controlá-los. Entretanto, para alcançar tal pretensão não seria possível a existência de um forte instrumento em favor dos cidadãos romanos. Por isso, os interditos precisavam perder sua força executiva!

Essas considerações são revelantes devido a pungente influência da forma processual do Direito Romano na formação do Processo Civil Brasileiro. É nesse contexto que se pretende estabelecer algumas ponderações. Em que medida influencia-se o predomínio da actio no atual Processo Civil Brasileiro? Seria um retorno ao passado quando se reluta em admitir juízos de cognição sumária? Como se mantém até os dias atuais, um procedimento em que se retira a força executiva das decisões? De que maneira o pensamento racional induziu a codificação do direito? 
Por óbvio, tais indagações têm por único objetivo levantar a discussão acerca da dificuldade de se implementar juízos de cognição sumária e examinar tal problemática nas raízes de formação do Processo Civil Brasileiro. Não se pretende nesse momento esgotar a temática apenas provocá-la. Pretende-se também destacar as tutelas de urgência como alternativa para transpor o procedimento ordinário.

Para tanto, organizou-se o presente artigo em quatro partes, sendo a primeira estas considerações iniciais. Posteriormente, far-se-á menção a codificação do Direito bem como sua interligação ao pensamento racional. Na terceira parte destaca-se sobre a diferenciação das tutelas de urgência e sua importância em decorrência de postergar o contraditório, transpondo até certo momento o procedimento ordinário. No último momento, nas considerações finais, reflete-se criticamente sobre os juízos de certeza em detrimento das cognições sumárias.

Para demonstrar tais objetivos, utilizou-se o método de abordagem dialético, tendo em vista a polêmica ainda existente na doutrina acerca da distinção entre as tutelas antecipadas e cautelares. A partir deste método aborda-se o tema com suas contradições internas e da sua relação e ou, interação com outros fenômenos de ordem histórica e jurídica, sem esquecer da complexidade social e das constantes modificações que se operam na sociedade e no Judiciário. Também, adotou-se o método de o histórico, tendo em vista que há necessidade de investigar as influências do racionalismo do século XVIII no Processo Civil Brasileiro compreendendo porque algumas idéias ultrapassadas persistem no Ordenamento Jurídico Brasileiro.

\section{Da codificação do Direito à "fluidez" da modernidade}

O direito em meados do século XVII presenciou uma tendência de codificação das fontes jurídicas. Conforme acima dito, o direito foi sendo identificado com a lei, a qual era uma revelação da vontade do príncipe, para esta época. Valendo-se das concepções de Bauman, o direito deveria ser substituído por um novo 'sólido' e este 'sólido' deveria assumir a posição de definitivo (2003, p.09). Associando-se essas idéias com o período da modernidade este 'sólido' seria a codificação das normas e, por conseguinte a elevação da lei como fonte primordial do direito.

Para o sociólogo Bauman, passamos de uma sociedade 'sólida' e 'pesada' para uma sociedade 'líquida' e 'fluída'. Essa nova sociedade em que ele denomina de 'líquida' atrela-se ao fato das constantes modificações sociais e incertezas fruto de um mundo essencialmente 
globalizado. Para a 'Era' das codificações do direito, o pensamento racional teve pungente influência.

A codificação levou a crença de que a racionalismo era capaz de descobrir normas seguras e certas. Assim, através do método lógico da "redução, dedução, conexão e demonstração" como refere a Martins Costa (2000, p. 153) era possível obter a segurança jurídica e a sistematização das normas em códigos.

Os pensadores desta época eram matemáticos e o conhecimento humano levava em conta apenas a razão. O desenvolvimento intelectual originou as idéias de liberdade política e econômica que eram defendidas pela burguesia. Os avanços tecnológicos levavam em conta a razão como sendo capaz de alcançar qualquer conhecimento. As idéias iluministas favoreciam o entendimento das ciências como equações algébricas, necessitando de sistematização e ordenação. As codificações surgem e refletem na tendência das cognições exaurientes, dificultando a utilização das tutelas de urgência.

Os Estados pretendendo o absolutismo necessitavam da certeza proporcionada pela matemática, para centralizar seus poderes na figura do soberano. Segundo Martins Costa:

\section{[...] ao mesmo tempo em que o Estado se 'absolutiza',e exatamente porque é 'absoluto', intenta unificar as fontes de produção jurídica na lei - concebida, esta, como expressão da vontade do soberano - e no ordenamento jurídico estatal, cuja expressão máxima é a vontade do príncipe. Ao absolutismo político corresponderá o absolutismo jurídico (2000, p.141). [grifo do autor]}

Assim, o direito foi compreendido como uma ciência lógica e explicativa, como uma simples operação algébrica. Por isso, diante da incerteza quanto às decisões jurídicas viu-se a necessidade de codificar o direito para existir segurança e certeza jurídica. Assim, começa o movimento de Codificação na Europa, pois era imprescindível para a manutenção dos Estados Absolutistas, à lei passar pelo crivo real. Nesse contexto, foi criado a ideologia da certeza jurídica.

Os códigos deste período deveriam ser estritamente aplicados tal qual diziam as normas, não existia espaço para interpretações. Buscava-se ainda que inconscientemente a segurança jurídica. O Juiz deveria ser "a mera boca que pronunciava as palavras da lei” numa tradição Montesquiana (CAPPELLETTI, 1993, p.32). 
Com o paradigma racionalista, ao Juiz caberia aplicar a lei, este era o 'sólido' construído durante a modernidade. Não se admite no paradigma racionalista a vontade e discricionariedade do Juiz, mas somente a 'intenção’ do legislador. Para o racionalismo sempre se deve buscar a vontade da lei, pois, segundo os ideais de Hobbes, citado por Baptista da Silva, a justiça do Juiz seria sempre injusta (2004, p. 97). Seguindo esse raciocínio, Baptista da Silva, argumenta que a forma linear de pensar afasta o jurista de operar com a realidade (2004, p. 109).

Posteriormente, no Estado Liberal, surge o princípio da separação dos poderes, desvalorizando o papel dos juízes frente aos demais poderes da república, atrelando o Poder Judiciário, na figura do Juiz, a meros aplicadores da lei. Para tanto, o direito passou a ser posto pelo Estado através da unificação de suas fontes de acordo com a vontade política do Estado.

Com as idéias da Revolução Francesa, marcando o início do Estado Liberal, percebese crescer constantemente o individualismo, ou seja, a concepção de 'liberdades individuais' gerava necessidade de revolução. Nesta senda, Baptista da Silva, revela grande influência desta concepção individualista no Processo Civil Brasileiro, assim relatando:

\begin{abstract}
A influência exercida pelo individualismo sobre o processo civil é enorme, uma vez que todos os institutos e o conjunto de categorias de que se utiliza a doutrina processual, foram concebidos para a tutela de direito e interesses individuais, a partir dos movimentos formadores do Mundo Moderno, especialmente através da influência das idéias do Renascimento e da reforma religiosa (2004, p.56)
\end{abstract}

Ademais, Baptista da Silva (2003) refere sobre os filósofos da Revolução Francesa, eliminando qualquer possibilidade de interpretação do direito. Em suas palavras "a produção do direito haveria de ser obra exclusiva do legislador que se supunha um super-homem iluminado, capaz de produzir um texto de lei tão claro e transparente que dispensasse o labor interpretativo" (2003, p. 32).

Posteriormente a Revolução Francesa, valendo-se do ideal de igualdade, estabelece-se a premissa de que todos são iguais perante a lei, e esta deve ser abstrata e aplicável a todos. Segundo Martins Costa (2000, p.169) "o direito se faz lei, geral e abstrata, e a lei, ou direito, encontra a sua forma, o código, conjunto unitário de leis, provindas de uma fonte, o Estado". A Revolução Francesa trouxe "o mito da lei, que passará a ser tida como fonte suprema, quase 
exclusiva, da produção jurídica", para a referida autora (2000, p. 178).

Esse modo de conceber o direito, como fonte adstrita e vinculada à lei, compromete o aprimoramento do processo civil para atender as demandas atuais. Baptista da Silva (2004) adverte como solução dos problemas atuais a utilização de remédios ultrapassados. Desse modo, é predominante o pensamento linear do século XVIII obstaculizando-se a tentativa de adequação processual aos novos litígios de uma sociedade eminentemente complexa.

Percebe-se uma estagnação do direito frente às ideologias passadas e isso também explica o descompasso entre as transformações sociais e o direito. Devido à racionalização do direito, as reformas não tutelam tempestivamente os clamores da sociedade. E este fato é atrelado à história porque não se consegue desvincular do paradigma racionalista do séc. XVIII. Conforme adverte o sociólogo Bauman os 'sólidos' são difíceis de serem 'derretidos' (2003, p.13).

A codificação afastou o direito dos conflitos sociais e, por sua vez, "o processo congelou-se no tempo", atrelado ainda hoje ao "componente ideológico inerente à ética do liberalismo" segundo Baptista da Silva (2003, p.35). Ou seja, o processo continua possuindo caráter autoritário e algemado ao paradigma racional, preterindo decisões sumárias.

Para compreender, o pensamento racional é definido por Thomas Kuhn (2001, p.13), como "as realizações científicas universalmente reconhecidas que, durante algum tempo, fornecem problemas e soluções modelares para uma comunidade de praticantes de uma ciência"[grifo do autor]. Assim, segundo o autor, a ciência normal se desenvolve por acúmulo de conhecimentos, nos quais levam a construção de uma teoria que posteriormente pode tornar-se um paradigma. Em outras palavras, seriam os sólidos cujo Bauman atribuí outrora como conceitos óbvios e certeiros (2003, p.15).

Para exemplificar esse acúmulo de conhecimentos expressado por Kuhn, pode-se verificar que o Direito processual civil, contém elementos de períodos anteriormente explicitados como o Direito Romano, Estado Absolutista, Estado Liberal, todos influenciando a construção de uma teoria que se pode tornar um paradigma. E assim, transformando-se em paradigma, fica difícil de derreter esse sólido construído ao longo dos tempos.

Desse modo, a ciência normal relaciona-se com o conceito de paradigma, ou seja, através da construção de uma teoria eleita por uma comunidade científica como paradigma, percebe-se a evolução e não revolução da ciência normal. Para Kuhn (2001, p.38) "uma teoria 
deve parecer melhor que suas competidoras, mas não precisa (e de fato isso nunca acontece) explicar todos os fatos com os quais pode ser confortada" para ser aceita como paradigma. O autor explica como a ciência normal evolui, porém, ressalta a revolução científica como uma quebra do paradigma anterior. Ou ainda, derretendo esse sólido como ressalta Bauman (2003, p.13).

Baptista da Silva, analisando essas suposições de Kuhn, sobre o progresso científico, menciona que o mesmo não acontece por acúmulos de conquistas de períodos históricos anteriores, mas pela constatação de que o paradigma atual não responde eficientemente aos problemas $(2004$, p.31). Dito de outro modo, percebe-se que as exceções superam as regras, ou seja, o atual paradigma racionalista não responde consideravelmente os problemas atuais.

É exatamente nesse contexto que se pretende chegar: - a codificação do direito; a sua vinculação à lei; a utilização do procedimento ordinário como regra, necessita ser superada, ou 'derretida', pois a modernidade atual é 'liquida', insegura, incerta e 'fluída' não cabendo mais essas velhas ideologias como solução aos atuais conflitos modernos. Seguindo esse raciocínio o atual processo de conhecimento não serve como meio para alcançar tempestivamente a proteção dos direitos. Nesse contexto, inserem-se as tutelas antecipatórias e cautelares como utilização alternativa ao procedimento ordinário.

\section{Apontamentos sobre as Tutelas de Urgência}

O caminho a seguir nesse momento é diferenciar as cautelares e antecipatórias para compreender-se a relevância dessas tutelas como institutos tempestivos. Assim, passa-se a contrapor o entendimento de renomados juristas em torno das características das cautelares e antecipatórias.

Teodoro Júnior, Lacerda, Zavascki e Marinoni convergem o entendimento afirmando não reconhecer um direito substancial de cautela aduzindo a tutela cautelar como instrumento para assegurar um processo principal. Em contraponto a este entendimento Baptista da Silva (2000, p.105 -6) e Pontes de Miranda enfatizam as cautelares como "segurança da execução" reconhecendo um direito substancial de cautela.

Iniciando a análise feita por Teodoro Junior percebe-se seu comprometimento com a doutrina italiana especialmente de Calamandrei, quando concerne as cautelares para conservar a permanência do "estado das pessoas, coisas e provas" (2002, p. 47). Assim, para Teodoro Júnior as cautelares têm função primordial de proteger a tutela do processo e não do direito. 
Nesse sentido, não se compõem à lide no processo cautelar, tendo em vista que as cautelares visam assegurar o resultado útil do processo principal.

Ainda ao definir a tutela antecipada, o autor considera como poder do Juiz de antecipar o resultado final do processo definitivo realizando a pretensão do autor imediatamente. Em oposição as cautelares apenas asseguram a pretensão do autor (2002, p. 90). Adverte, porém que não constitui faculdade do Juiz em deferir ou não a tutela antecipada requerida pela parte, mas um direito subjetivo processual caso estejam preenchidos os seus requisitos (2002, p. 439). Para Teodoro Júnior a tutela antecipada adianta a concessão do provimento antes de apreciar toda a controvérsia devido a necessidade de proteção. Seguindo seu raciocínio reconhece "a existência de casos em que a tutela somente servirá ao demandante se deferida de imediato" (2002, p. 439). Desse modo, percebe-se que a tutela antecipada transpõe os entraves do procedimento ordinário quando defere-se imediatamente a pretensão do autor.

Entretanto, na posição assumida por Teodoro Júnior, percebe-se o seu comprometimento com o racionalismo, ou seja, compreende as tutelas cautelares a partir da influência italiana e do Direito Romano. Nesse sentido, as cautelares são sempre dependentes do processo principal bem como não compõem uma lide, razão pela qual não admite a provisoriedade da decisão na cautelar como jurisdicional. Seu posicionamento está agarrado ao procedimento da actio do direito romano quando se abandona os interditos tendo em vista que as decisões são provisórias, sendo necessário um procedimento posterior. Utilizando a expressão de Bauman (2003) esse é um sólido que necessita derreter.

Seguindo esse pensamento, Lacerda (2001, p.14) chega admitir a existência de cautelares administrativas revelando, da mesma forma que Teodoro Júnior, o seu comprometimento com o paradigma racionalista, principalmente porque vincula ao conceito de jurisdição à composição da lide bem como seu caráter meramente declaratório. No seu ver, a composição da "lide parcial" obriga o Juiz a prestar jurisdição pois, caso contrário, estar-se-á diante de uma atividade administrativa apenas dirigindo o processo através de seu poder administrativo (2001, p. 19). Em outras palavras, sua visão é ainda envolvida com o Direito Romano onde se retirou dos interditos do pretor o caráter jurisdicional considerando como atividades derivadas do poder de imperium do pretor sendo então meramente administrativas.

Tal comprometimento é facilmente percebido em Lacerda (2001, p.14) porque ao classificar as cautelares, segundo "a natureza da tutela cautelar" divide-as em jurisdicionais e administrativas, sendo esta mera atividade do "magistrado de dirigir o processo", consistindo- 
se num "poder de polícia" o resguardo de bens e pessoas requeridas pelas partes, ou decretadas de ofício pelo Juiz (2001, p.18- 23). Nas cautelares administrativas, não existe lide ou encontra-se fora da lide, da mesma forma que não existe sentença.

De forma enfática Lacerda registra que o Juiz não decide nas cautelares administrativas, tendo em vista, no seu pensamento, não existir lide nestas demandas. Entretanto, tem pertinência a crítica realizada por Baptista da Silva (2000, p. 45) quando afirma a existência de decisão do Juiz, pois ele sempre terá duas alternativas, deferindo ou indeferindo o pedido, salientando-se a possibilidade de decisões provisórias sobre a lide, realizadas em torno de juízo de verossimilhança, constituindo-as como ato jurisdicional.

$\mathrm{Na}$ ótica de Zavascki, a tradicional classificação das tutelas cautelares como um tertium genus é ineficaz para diferenciá-la das outras tutelas jurisdicionais. Assim, no seu ver "o critério diferenciador adotado, baseado na natureza da atividade jurisdicional, serve para distinguir a tutela cognitiva da executiva, mas não se presta para diferenciar das duas, a tutela cautelar" (2000, p.13). Seguindo esta linha de raciocínio, classifica as tutelas como provisórias e definitivas. As tutelas definitivas são caracterizadas pela cognição exauriente preconizando o valor da segurança jurídica, marcada ainda pela imutabilidade advinda da coisa julgada. As tutelas provisórias priorizam o valor da efetividade devido à necessidade de urgência tendo cognição sumária devido produzir efeitos temporários (ZAVASCKI, 2000, p.38). As cautelares e antecipatórias inserem dentre as tutelas provisórias.

Nesse cenário, Marinoni apresenta como característica peculiar das cautelares o fato de não realizar a função que se esperar da tutela definitiva, apenas limitando-se a assegurar a sua efetividade (2004, p.243). Em oposição, as tutelas antecipadas visam a realização e, por conseqüência, a satisfação da pretensão do autor. Ressalta também, a importância das tutelas antecipadas no sentido de "quebrar a regra de que não há execução no curso do processo de conhecimento" (2004, p. 244).

Seguindo esse raciocínio Marinoni, pretende demonstrar que esse juízo de certeza sempre foi obstáculo para as tutelas antecipatórias. Assim, explica a premissa onde se preteriu a execução por medo do arbítrio do juiz estipulando-se uma ampla defesa ao réu e consagrando o principio do contraditório. Por esses motivos, explica que as novas necessidades contemporâneas não podem esperar o tempo de formação desse pressuposto lógico-jurídico de certeza jurídica através do processo de conhecimento para impedir a satisfação do direito do autor (2004, p.246). 
Devido a esse contexto atual de urgência na proteção dos direitos, merece ser apreciada a doutrina de Pontes de Miranda e Baptista da Silva devido a posição ímpar em torno das cautelares. Ambos os processualistas reconhecem um direito substancial de cautela e são praticamente os únicos em afirmar que as cautelares não têm por finalidade ser instrumento do processo principal.

$\mathrm{Na}$ ótica de Baptista da Silva as cautelares têm por finalidade a proteção jurisdicional de um direito subjetivo ou outros interesses legítimos, e, principalmente, proteger pretensões de direito material, quando seu titular alegue encontrar-se sob ameaça de um dano irreparável. Adverte inicialmente, que não se deve conservar o legado da doutrina italiana, segundo o qual, a tutela cautelar busca dar uma solução imediata aos problemas de direito material devido uma disfunção do processo comum, pois, assim, jamais irá se distinguir a tutela cautelar da antecipada (2000 p.17-30). Nesse contexto, é inerente o resquício do paradigma racionalista, pois para o processualista "enquanto o Brasil não criar jeito e buscar sua identidade cultural, continuaremos a importar obsolescências, relíquias culturais da velha Europa" (2000, p.32).

Neste contexto, para Baptista da Silva, é necessário à existência da tutela cautelar a temporariedade, a situação cautelanda, a sumariedade da cognição, a iminência de dano irreparável, e a sentença mandamental. Entretanto, para analisar tais características da tutela cautelar é preciso diferenciar alguns conceitos como provisoriedade, satisfatividade, antecipação, entre outras importantes definições para compreender o intuito acautelatório das cautelares.

O primeiro critério a ser diferenciado para o processualista são os conceitos de satisfazer e assegurar. Ao seu ver, quando na doutrina italiana se contrapõe a cautelaridade à definitividade e, não, à satisfatividade, ocorre o primeiro empecilho para distinguir as tutelas de urgência. Para os carnellutianos, não se pode falar em satisfação antes da sentença definitiva e em razão disso, não há diferença entre cautelar e antecipação satisfativa. Assim, tanto a tutela antecipada e a cautelar são provisórias, não havendo critério para distingui-las. Por isso, Baptista da Silva entende que a satisfatividade deve contrapor-se a cautelaridade e não a provisoriedade. Esclarece a satisfatividade como realização concreta no plano "das relações humanas" (2000, p.34 -8). Nas suas palavras, "exercer a função de instrumento que assegura a realização dos direitos subjetivos. Assegura, porém não satisfaz o direito assegurado" (2000, p.39) [grifo do autor]. Dito de outro modo, as cautelares asseguram uma futura satisfação, mas não satisfazem, ainda que provisoriamente o direito do autor. Exemplo disso, Baptista da Silva 
refere que no seqüestro de um bem em litígio, de acordo com o art. 822, I, do CPC, quando o juiz decreta o seqüestro do bem, objeto de litígio numa ação principal, e manda depositar com um terceiro esta apenas assegurando a pretensão do autor na ação principal e jamais satisfazendo a pretensão deste autor (2000, p. 42).

Nesse passo, outro ponto de distinção concebida para o doutrinador é a provisoriedade e temporariedade. Quanto à temporariedade, a duração da medida deve-se dar enquanto perdurar a situação de perigo, a qual justificou seu deferimento. Assim, Baptista da Silva opõem-se a provisoriedade das cautelares, pois pressupõem outro provimento que substituirá tornando-se definitivo. A provisoriedade é característica das tutelas antecipatórias nas quais ao final será substituída por uma decisão final. Seguindo essa linha de raciocínio, Baptista da Silva (2000, p. 47) registra que as tutelas antecipatórias satisfazem à pretensão do autor, constituindo-se verdadeiras sentenças liminares, baseadas em juízo de verossimilhança.

A situação cautelanda reflete no plano dos fatos uma necessidade de proteção devido à ameaça surgida contra seu direito ou pretensão. Nesse contexto, é necessário um provimento cautelar para assegurar este direito ameaçado. A proteção a direitos emergencialmente postos a perigo, somente às tutelas cautelares poderão atender tempestivamente, salientando, em sua opinião, serem instrumentos para a proteção dos direitos e no sentir de Pontes de Miranda seriam "segurança da execução" (2000, p.53).

Outra distinção na teoria de Baptista de Silva é o pressuposto do perigo de dano iminente e irreparável ao invés do periculum in mora. Nesse sentido, afasta a idéia da demora num processo principal, pois esta pressupõe um provimento de natureza satisfativa constituindo-se um remédio da morosidade da prestação jurisdicional. Entende apenas a necessidade de assegurar a iminência de dano irreparável advindo de uma situação fática para que se torne possível à realização desse direito (2000, p.55-63).

A sumariedade da cognição diz respeito ao fumus boni iuris entendido como um juízo de verossimilhança, ou seja, é analisada a aparência do direito não sendo possível uma cognição exauriente, porque implicaria em destruição da proteção na situação fática. Assim, a simples evidência do direito, deve ser analisada mediante um juízo de probabilidade, atendendo a pretensão de proteção do autor efetivamente. Caso contrário, estar-se-ia procurando um juízo de certeza, tolhendo a utilidade prática das tutelas assegurativas. No seu dizer define "toda medida cautelar, adotada sob o signo da urgência, sustenta-se necessariamente num juízo de simples verossimilhança (fumus boni iuris), que se expressa sob 
a forma de cognição sumária" (2000, p.79) [grifo do autor].

A sentença mandamental é inerente da tutela cautelar, pois segundo Baptista da Silva, assim como nos interditos romanos, a ação cautelar, não tem sua proteção efetivada pelas tutelas jurisdicionais comuns necessitando de uma sentença mandamental. Na opinião do jurista a mandamentalidade possui um caráter declarativo forte e outro administrativo, onde prepondera o imperium sobre a notio (2000, p.81).

Nesse passo, sintetizando as concepções de Baptista da Silva, acerca das tutelas de urgência, dividindo-as em dois grandes grupos, quais sejam as tutelas cautelares e as tutelas de urgência satisfativa. Desse modo, dispõe que as tutelas cautelares tem como pressuposto o perigo de dano irreparável e as tutela de urgência satisfativa provisional, possuem como pressupostos a verossimilhança da alegação e o perigo da demora. Seguindo esse raciocínio as cautelares possuem requisitos menos rigorosos para o seu deferimento, bastando analisar apenas o perigo de dano irreparável.

Nesse mesmo sentido Pontes de Miranda, vê-se a pretensão das cautelares para a segurança. Discorda, quando as cautelares são colocadas como mecanismos acessórios de um processo principal. Para esclarecer tal entendimento enfatiza que as cautelares não são sempre instrumentos da eficácia de uma decisão definitiva. Na opinião do autor é lamentável tal confusão, explicando que se confundiria o que previne com algo meramente preparatório. Em suas palavras, o que prepara, "põe, antes, o mesmo" e o que previne, "chega, antes de modo distinto" (1976, p.8).

E também coloca que "não há propriamente provisoriedade na decisão que neles se profere; há cautela, há segurança" (1976, p. 7). Assim, enfatiza a tutela jurídica da segurança e a pretensão a execução sem satisfação como características das cautelares, pois caso contrário estar-se-ia adiantando e preparando a cognição para a execução. Assim, para Pontes de Miranda a pretensão das cautelares será prevenir e assegurar sem satisfazer. Ao seu dispor nas cautelares "pode-se falar, sem risco, da ação de segurança, ou de ação cautelar, como de pretensão à segurança, ou pretensão à cautela" (1976, p.21).

No pensamento de Pontes de Miranda, a característica principal das cautelares é proteção rápida sem satisfazer o direito ou a pretensão. Registra-se, ainda, crítica, quando aduzem que as cautelares não vem sozinha. Aponta a circunstância de a cautela poder ser em função de lide em andamento ou futura. Ademais, para o doutrinador não basta à situação de 
urgência para caracterizar a tutela cautelar é necessário o perigo iminente para a proteção de um direito que poderá ser violado (1976, p.26).

De todo o exposto, percebe-se que o Direito Processual agarrou-se a 'ordinarização', e as cautelares foram utilizadas como "válvula de escape" para atender os clamores da sociedade, como adverte Marinoni (2003, p.62). Em suas palavras, "a tutela cautelar transformou-se em técnica de sumarização do processo de conhecimento e, em última análise, em remédio contra a ineficiência do velho procedimento ordinário [...]". Por isso, sob a necessidade de uma tutela tempestiva, utiliza-se das tutelas de urgência para assegurar efetividade as demandas. Essa é a importância de estudar as tutelas de urgências tendo em vista constituírem um instrumento processual efetivo para harmonizar a morosidade da prestação jurisdicional.

\section{Considerações Finais}

O contexto atual da sociedade contemporânea exige do direito novas perspectivas no que concerne a forma de pensar, aplicar e interpretar a lei. Assim, o direito para atender os clamores da sociedade onde tudo é urgente e incerto, precisa adaptar-se as essas novas exigências. Entretanto, isso somente é possível quando se (re)pensa criticamente alguns conceitos e dogmas vigentes na ciência jurídica. Assim, o direito e seu processo enquanto instrumento para a pacificação dos conflitos sociais, prescindem de uma abertura as transformações sociais para encontrar novas respostas.

Para tanto, inicialmente o processo deve ser compreendido a partir de sua história, de sua origem e estar atento as brutais mudanças sociais procurando adaptar-se as novas exigências. Com isso, surgem à necessidade de demandas céleres, não sendo plausível a utilização de cognições exauriente como regra de procedimento, devido à morosidade e consequentemente ineficiência para resolução dos conflitos. Neste contexto, imperam-se as formas sumárias de cognição, como as tutelas de urgência, devido atender rapidamente o direito material buscado em juízo ultrapassando a cognição exauriente do procedimento ordinário.

Seguindo esse viés, importante inovação no Direito Processual Brasileiro, foi à inserção da tutela antecipada proposta por Baptista da Silva. Tal tutela de urgência proporciona a aproximação do processo aos direito materiais atendendo no plano da realidade a pretensão pleiteada em juízo. Nesse sentido, com a tutela antecipada rompe-se com a arcaica estrutura da 
declaração e posterior execução e abre-se caminho para a execução antes da cognição. Dito de outro, modo rompe-se com a forma linear de pensar, que sempre prescinde-se de uma declaração ao final do processo de conhecimento para num momento posterior mudar a situação no mundo dos fatos. No entanto, a tutela antecipada, tão logo foi incorporada ao ordenamento, ela foi ordinarizada, na medida em que mantém-se a cisão entre cognição e execução.

A intenção das tutelas de urgência foi benéfica, mas o sistema as ordinarizou, na medida que resiste à sumarização da demandas e aos juízos de probabilidade. A forma racional e geométrica de pensar o direito ultrapassou vários séculos podendo-se dizer que se retorna ao passado quando não se admite as formas de cognição sumária. Nota-se que os juízos de certeza prevalecem em detrimento dos juízos de verossimilhança tão importantes para a construção de uma tutela que atenda as situações emergenciais da sociedade globalizada. Ou seja, o paradigma racionalista não consegue conviver com juízos de probabilidade e prende o sistema, no caso o direito, aos juízos de certeza. O paradigma não sabe lidar com os múltiplos futuros da modernidade, crendo em uma única verdade. Como dito acima, o 'sólido' construído com a Codificação do Direito tende reduzir o direito a uma só resposta como era possível em outras épocas onde os conflitos eram simplistas.

Sobre esse 'sólido', as soluções dos litígios, continuam agarradas às cognições exauriente. Impedindo de possuírem, como regra, tutelas tempestivas de proteção dos direitos. As tutelas de urgência são vistas como exceções e sobre o paradigma racionalista, elencando como valores a segurança jurídica bem como a previsibilidade das decisões, não se poderá conceber a prevalência das cognições sumárias, pois estas não se adaptam aos valores do racionalismo.

Adverte-se, porém que não se esta criticando totalmente a codificação do Direito, pois ela teve importância no séc.XVII para limitar a arbitrariedade dos Reis. Apenas constata-se que a codificação afastou o direito dos conflitos sociais e na contemporaneidade não pode admitir, a morosidade da prestação jurisdicional, tolhendo o acesso efetivo à Justiça. Ou seja, o processo continua possuindo caráter autoritário e algemado ao paradigma racional, preterindo decisões sumárias.

Por conseguinte, a dinâmica social encontra-se em descompasso com o direito e consequentemente com o Processo Civil, numa sociedade onde impera a urgência. Nesse contexto, reside a importância das cautelares vistas como meio tempestivo e célere para tutelar 
o possível perigo de dano iminente constituindo-se em proteção efetiva atendendo as necessidades contemporâneas. Por essa razão, deve-se refletir sobre a utilização das cautelares e antecipatórias como meios eficazes para tutelar tempestivamente os direitos lesionados. Na verdade, não seria conveniente aceitar essas tutelas de cognição sumária como regra e reservar o procedimento ordinário para situações complexas que realmente necessitam de cognição exauriente?

\section{Referências Bibliográficas}

ARENHART, Sérgio Cruz; MARINONI, Luiz Guilherme. Manual do Processo de Conhecimento. São Paulo: Revista dos Tribunais, 2004.

BAPTISTA DA SILVA. Processo e Ideologia. Rio de Janeiro: Forense, 2004.

Curso de Processo Civil. Processo de Conhecimento. 3.ed.São Paulo: Revista dos Tribunais, 2000.

2003.

Processo e Ideologia. Revista de Processo, São Paulo, n. 110, p.19-36, abr -jun,

BAUMAN, Zymunt. Modernidade Líquida. Rio de Janeiro: Jorge Zahar Ed. 2001.

CAPPELLETTI, Mauro. Juízes legisladores? Traduzido por Carlos Alberto Álvaro de Oliveira. Porto Alegre: Sergio Fabris Editor. [1993].

CARMIGNANI, Maria Cristina da Silva. A Origem Romana da Tutela Antecipada. São Paulo: LTr, 2001.

CRUZ E TUCCI, José Rogério; AZEVEDO, Luiz Carlos. Lições de História do Processo Civil Romano. 1. ed., São Paulo: Revistas dos Tribunais, 2001.

FIUZA, César (coord).; BIRCHAL, Alice de Souza; OLIVEIRA, Allan Helber de et al. Direito Processual na História. Belo Horizonte: Mandamentos, 2002.

FERREIRA, Pinto. Medidas Cautelares. Rio de Janeiro: Freitas Bastos, 1983.

KUHN, Thomas S. A Estrutura das Revoluções Científicas. Traduzido por Beatriz Vianna Boeira, Nelson Boeira. São Paulo: Perspectiva S. A, [2001].Tradução de: The Structure of Scientific Revolutions.

LACERDA, Galeno.Comentários ao Código de Processo Civil. 8 ed.Rio de Janeiro: Forense, 2001,v.VIII, Tomo I.

MARTINS COSTA. Judith. A Boa-fé no Direito Privado. 1.ed. São Paulo: Revista dos 
Tribunais, 2000.

PONTES DE MIRANDA, Francisco Cavalcanti.. Comentários ao Código de Processo Civil. Rio de Janeiro: Forense, 1976, Tomo XII.

THEODORO JÚNIOR, Humberto. Processo Cautelar. 20 ed. São Paulo: Universitária de Direito Ltda, 2002.

WOLKMER, Antonio Carlos. História do Direito no Brasil. 2 ed. Rio de Janeiro : Forense , 2000 .

ZAVASCKI, Teori Albino. Antecipação de Tutela. 3 ed. São Paulo: Saraiva, 2000. 